\title{
REENGINEERING OF BUSINESS PROCESSES AND IMPROVE THE SALES SYSTEM BY 1C IN PHARMACIES
}

\author{
Gulnara A. Gareeva ${ }^{1}$ \\ Diana R. Grigoreva ${ }^{2}$
}

\begin{abstract}
: sales activities is one of the main elements of the production and commercial activities. It affects all stages of production by ensuring the flow of financial resources, their circulation. The quality of the Sales Department's work depends largely on the effectiveness of the entire enterprise. Effective sales activities has a positive social and economic impact on individual employees, Enterprise and society as a whole. This work describes a project subsystem "sales management, sales task is implemented, evaluated the effectiveness of the implementation of the specified task. The practical value of

activities of the pharmacy network. Results can be described as effective as integral indicators of the economic efficiency of the project equal: the total cost of the development tasks-40080.66 rub; savings: 5305.18 rub. per month, 63662.16 rubles. in the year, the net present value of-8709.12 rub; payback period-simple 9.4 months, discounted payback period (at a discount rate of $8 \%)-10.8$ months, internal rate of return$46.05 \%$.Introduction of Sales Accounting tasks "gives the management effect and synergistic effect that is associated with the use of the results of this task on other tasks.
\end{abstract} the study is that the draft can be used for all-round automation of enterprise management. To redesign processes in sales management subsystem uses the reengineering of business processes. For selected key business processes, there is a set of indicators on the economic
Keywords: marketing, reengineering, pharmacy chain, information system, a business process.

\section{Introduction}

\footnotetext{
1 Kazan Federal University, Nabereznye Chelny. e-mail: gagareeva1977@mail.ru tel. 89061233060.

2 Kazan Federal University, Nabereznye Chelny. e-mail: gagareeva1977@mail.ru tel. 89061233060.
} 
Currently, under conditions of high competition, the company requires a set of activities in the field of marketing. And this is possible only if carried out targeted sales management. Such management should consist of several stages:

- planning the establishment of the programme of action;

- Organization of labour together link subjects of labour and means of labour in conditions of functioning of the enterprise;

- demand generation and sales promotion-implementation of a range of activities aimed at the sale of products.

The aim of the study is to improve the business sales process, in particular the development of information system of the enterprise, allowing you to improve sales. Process improvement is considered "classical" concept of improving operating efficiency business. This approach involves a detailed and systematic review of existing process with a view to finding possible ways of improving it, or, if necessary, a radical redesign.

\section{Materials and Methods}

Researchers distinguish five main methods to achieve the goals of
Periódico do Núcleo de Estudos e Pesquisas sobre Gênero e Direito Centro de Ciências Jurídicas - Universidade Federal da Paraíba V. 8 - No 05 - Ano 2019

ISSN | 2179-7137 | http://periodicos.ufpb.br/ojs2/index.php/ged/index

improving business processes in organizations: a quick decision analysis technique (FAST); benchmarking process; Re-engineering process; engineering process; Reengineering process [1]. Business process reengineering is the most radical of the above techniques to improve business processes, with the exception of engineering, because in the literal sense is not an improvement, but rather a method of process control. Object is reengineering business processes that define the work of the organization. Reengineering can be done repeatedly until the majority of the company's processes will not be completely transformed [2],[3].Thus, the work is divided into phases, each of which has a clear goal is to significantly improve the work of the organization. Appointment information system is being designed to improve the use of computer technology in the production activity of pharmacies, through a better distribution of the input and output of information between the various units pharmacy network [4].Also the appointment of an information system is the automation of pharmacy network management process while maintaining full harmonization and integration of information across 


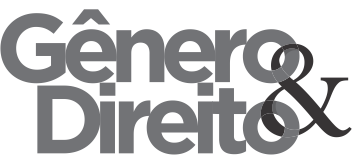

Periódico do Núcleo de Estudos e Pesquisas sobre Gênero e Direito

Centro de Ciências Jurídicas - Universidade Federal da Paraíba

V. 8 - No 05 - Ano 2019

ISSN | 2179-7137 | http://periodicos.ufpb.br/ojs2/index.php/ged/index

pharmacy network. Selection of subsystems according to the process-task approach should be based on business processes and information system-tasks allocation for these business processes tasks that would improve the costeffectiveness of the system. The purpose of creation of management information system of pharmacy network is to improve the efficiency and effectiveness of production, reaching break-even, sustainable profits [5]. Business process management organization involves continuous improvement and optimization, so essential instruments process management approaches and methods to improve business processes [6]. For a description of the organizational and logical entity subsystems used model IDEF3 [4],[5]. For further analysis of sales management subsystem is considered. Sales management subsystem includes task:

- Calculate your needs in product marketing;

- Formation of requests for provision of goods;

- Recognition of orders;

- Taking into account the actual cost of sales;

- Calculation of indicators of effectiveness of sales activity.

Figure 1 presents the logical model of the organizational subsystem «sales management».

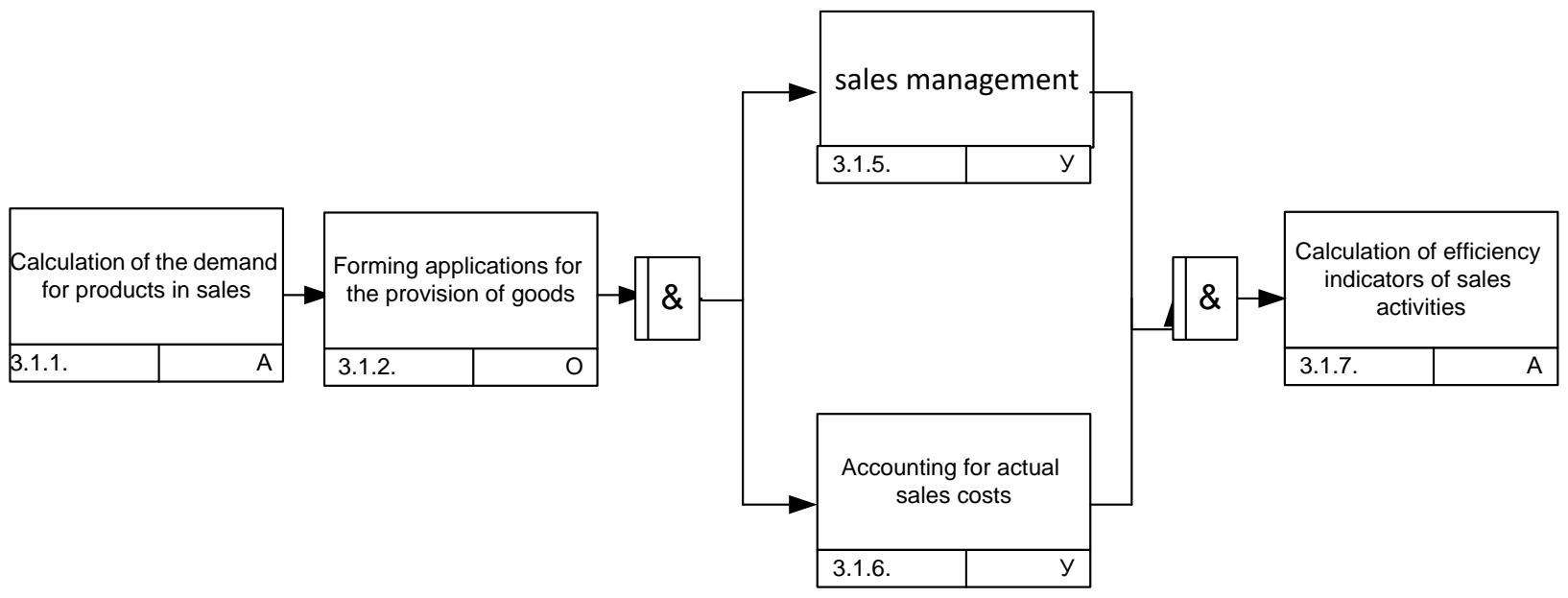

Figure 1. -Organizational and management subsystem logic model «Sales management».

The aim of developing a sales task is the analysis of all the indicators of subsystem "sales management. The input information is data to log tasks and used 
Periódico do Núcleo de Estudos e Pesquisas sobre Gênero e Direito

Centro de Ciências Jurídicas - Universidade Federal da Paraíba

V. 8 - No 05 - Ano 2019

ISSN | 2179-7137 | http://periodicos.ufpb.br/ojs2/index.php/ged/index

for its decision; output information to be tasks are the results of the solution of the presented in the form of documents and problem. Organizational and logical reports in the database. Input and output entity meet the challenge of "sales" is information arrays tasks are presented in presented in Figure 2.

the table. The result of the development

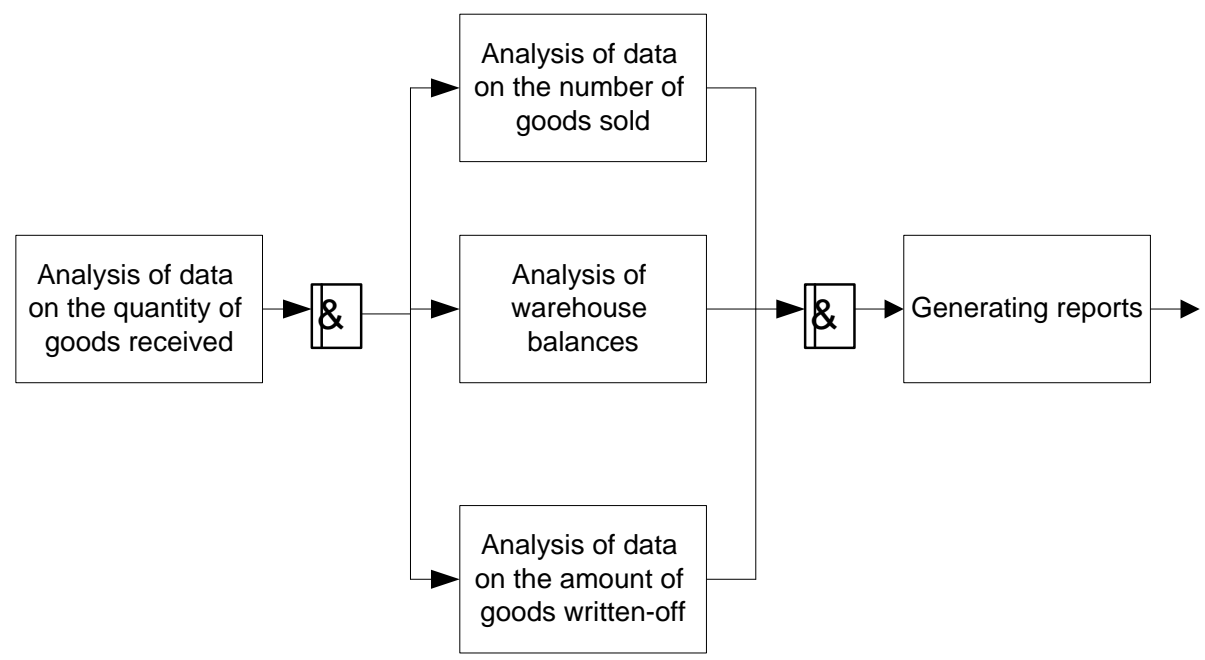

Figure 2. -Organizational and logical entity solutions « sales»

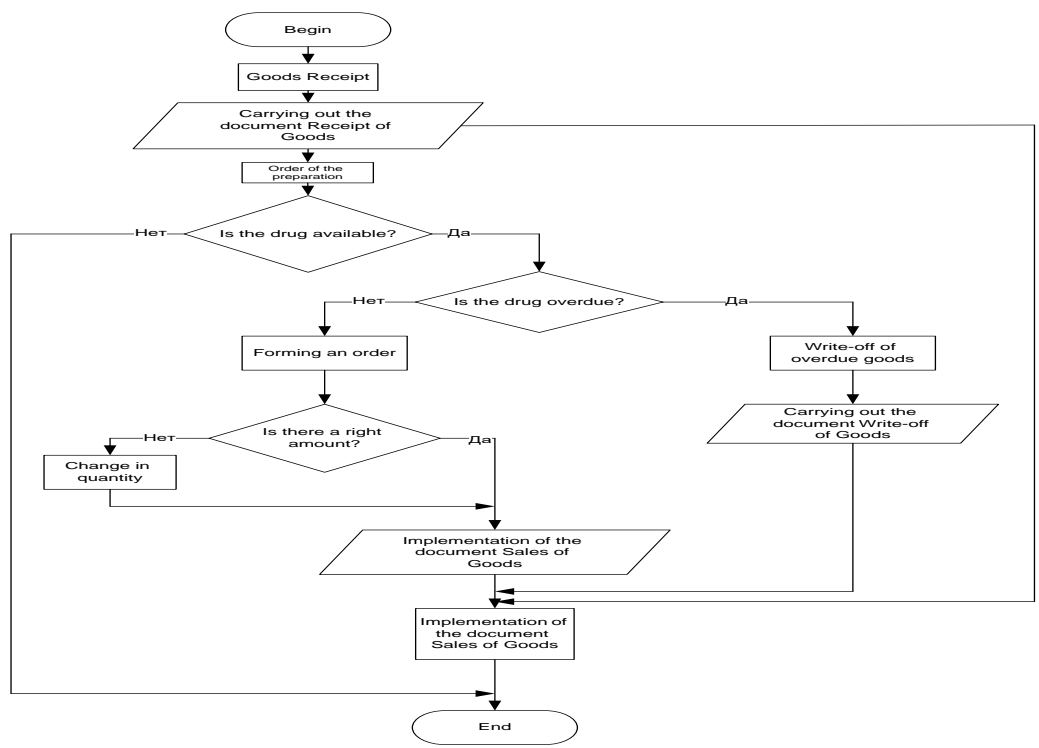

Figure 3. -Algorithm for solving the problem of "sales" 
Platform «1C: Enterprise 8.2.»

is selected as a software development. Application development is conducted on the built-in programming language (object-oriented language).

\section{Results and Discussion}

The cost of solving business problems without the use of an information system is equal to 9948.72 rubles, the cost of solving business problems using information system a month is equal to 4643.53 rubles. The structure cost changes using the software reflects the table 1 and Figure 4.

Table 1. Structure of cost changes using the software

\begin{tabular}{|l|l|l|l|l|}
\hline & \multicolumn{1}{|c|}{$\begin{array}{r}\text { Cost budget } \\
\text { without } \\
\text { software }\end{array}$} & $\begin{array}{r}\text { Structure of } \\
\text { changes in } \\
\text { with software }\end{array}$ & $\begin{array}{r}\text { Structure of } \\
\text { costs from the } \\
\text { use of } \\
\text { softwange in } \\
\text { rubles. } \\
\text { costs from the } \\
\text { use of } \\
\text { software, } \%\end{array}$ \\
\hline fixed assets of & 6666,67 & 3083,33 & 3583,33 & 116,22 \\
\hline Business Products & 180,00 & 180,00 & 0,00 & 0,00 \\
\hline Material costs & 1162,05 & 410,20 & 751,85 & 183,29 \\
\hline Other costs & 20,00 & 10,00 & 10,00 & 100,00 \\
\hline Labor costs & 1920,00 & 960,00 & 960,00 & 100,00 \\
\hline The overall result & $\mathbf{9 9 4 8 , 7 2}$ & $\mathbf{4 6 4 3 , 5 3}$ & 5305,18 & 114,25 \\
\hline
\end{tabular}




\section{Structure of changes in costs from the use of software, rubles.}

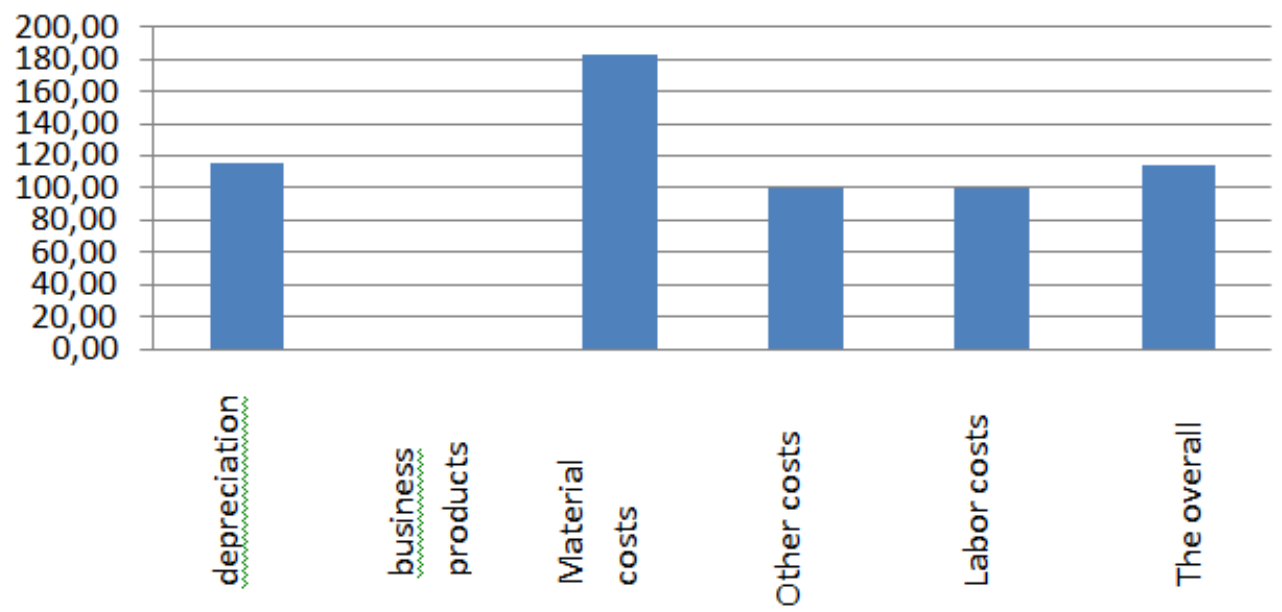

Figure 4. -The structure of cost changes using the software

Results can be described as effective as integral indicators of the economic efficiency of the project when the horizon of calculation 1 year (12 months) is equal to: The total cost of the development tasks-40080.66 rub; savings: 5305,18 rub. per month, 63662,16 rubles. in the year.Net present value-8709,12 rub; Payback periodsimple 9,4 months and discounted payback period (at a discount rate of 8\%)-10,8 months. IRR-46,05\%.

Introduction of "Sales" gives the management effect and synergistic effect that is associated with the use of the results of this task on other tasks. 


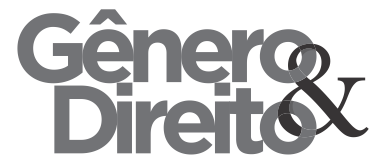

To deal effectively with all organizational, analytical and accounting tasks proposed enterprise information system by applying processtask technology [9]. The project information system includes subsystems corresponding to enterprise business processes and fully reflects the real tasks of the enterprise. The draft revealed links between subsystems and its tasks [10]. In the proposed draft "sales management subsystem provides organizational and logical entity decision of its tasks, internal and external communication. Developed the "sales", "sales management subsystem" and economic rationale for the development and implementation of tasks. The considered task is performed manually on the enterprise that is quite time consuming process. Therefore, for the effective work of manpower automation of this task, in connection with which the developed program product is recommended for use in pharmacies in the city of Naberezhnye Chelny.

\section{Conclusions}

Introduction of Sales Accounting tasks "gives the management effect and synergistic effect that is associated with the use of the
Periódico do Núcleo de Estudos e Pesquisas sobre Gênero e Direito Centro de Ciências Jurídicas - Universidade Federal da Paraíba V. 8 - No 05 - Ano 2019 ISSN | 2179-7137 | http://periodicos.ufpb.br/ojs2/index.php/ged/index results of this task on other tasks. Calculation of economic efficiency of software development solutions to business challenges based on the method of payments flows "("Cash Flow") using the differential approach. Considered from an economic point of view the project is effective and appropriate for implementation.

\section{Acknowledgements}

The work is performed according to the Russian Government Program of Competitive Growth of Kazan Federal University.

\section{References}

Baldin, K.V. Informacionnye sistemy $\mathrm{v}$ ehkonomike: Uchebnik / K.V. Baldin, V.B. Utkin. - M.: Dashkov i K, -2013. $395 \mathrm{P}$.

Bodrov, O.A. Predmetnoorientirovannye ehkonomicheskie informacionnye sistemy: Uchebnik dlya vuzov / O.A. Bodrov. - M.: Gor. liniyaTelekom, -2013. - 244 P.

Kocyuba I.YU., CHunaev A.V., SHikov A.N. Osnovy proektirovaniya informacionnyh sistem: Uchebnoe 


\section{Gâners:}

posobie. - SPb: Universitet ITMO, 2015.

-206 P.

Gareeva, G.A. Forecasting techhiques in the research rail market / Gareeva, G.A., Grigoreva, D.R., lysanov, D.M. // International Journal of Applied Engineering Research (IJAER). - 2016. - pp.10472-10474.

Pierigè, $\quad$ F., Bigini, $\quad$ N., Rossi, L., Magnani, M. Reengineering red blood cells for cellular therapeutics and diagnostics // Wiley Interdisciplinary Reviews: Nanomedicine and Nanobiotechnology.-2017.-v. 9(5).-pp. $110-118$

Koeckert,

M.S., Ursomanno, P.A., Williams, M.R., Grossi, E.A., Galloway, A.C. Reengineering valve patients' postdischarge management for adapting to bundled payment models / Journal of Thoracic and Cardiovascular Surgery, 154(1), 2017, pp. 190-198.

Gareeva, G.A. Comprehensive Assessment of the reliability of the bank with the application of statistical methods / Gareeva, G.A., Grigoreva, D.R. // Academy of Strategic
Periódico do Núcleo de Estudos e Pesquisas sobre Gênero e Direito Centro de Ciências Jurídicas - Universidade Federal da Paraíba V. 8 - No 05 - Ano 2019 ISSN | 2179-7137 | http://periodicos.ufpb.br/ojs2/index.php/ged/index

Management Journal.- 2016.- vol.15.pp.29-33.

Grigoreva, D.R., Faizullina, A.G. The degree of participation indicator of sales of livestock products in the main social factors / Grigoreva, D.R., Faizullina, A.G. // Journal of Organizational Culture, Communications and Conflict.2016.- v.20.- pp.68-79.

Balan, S. Using simulation for process reengineering in refractory ceramics manufacturing - a case study // International Journal of Advanced Manufacturing Technology.- 2017.- V. 3, Issue 5-8. pp. 1761-1770.

Nekrasov, R.Y., Tempel, Y.A., Tempel, O.A. Innovative model of business process reengineering at machine building enterprises // IOP Conference Series: Earth and Environmental Science.- 2017.-v. 87(8).-pp. 19-28 